\title{
Valorization of Biodiesel Byproduct Crude Glycerol for the Production of Bioenergy and Biochemicals
}

\author{
Niravkumar Mahendrasinh Kosamia ${ }^{1,2}$, Mahdieh Samavi ${ }^{1,2}$, Bijaya Kumar Uprety ${ }^{2}$ and \\ Sudip Kumar Rakshit 1,2,3,* \\ 1 Department of Biotechnology, Lakehead University, Thunder Bay, Ontario, ON P7B 5E1, Canada; \\ nkosamia@lakeheadu.ca (N.M.K.); msamavi@lakeheadu.ca (M.S.) \\ 2 Biorefining Research Institute (BRI), Lakehead University, Thunder Bay, Ontario, ON P7B 5E1, Canada; \\ bijayauprety@gmail.com \\ 3 Department of Chemical Engineering, Lakehead University, Thunder Bay, Ontario, ON P7B 5E1, Canada \\ * Correspondence: srakshit@lakeheadu.ca
}

Received: 12 May 2020; Accepted: 29 May 2020; Published: 1 June 2020

check for updates

\begin{abstract}
The rapid growth of global biodiesel production requires simultaneous effective utilization of glycerol obtained as a by-product of the transesterification process. Accumulation of the byproduct glycerol from biodiesel industries can lead to considerable environment issues. Hence, there is extensive research focus on the transformation of crude glycerol into value-added products. This paper makes an overview of the nature of crude glycerol and ongoing research on its conversion to value-added products. Both chemical and biological routes of glycerol valorization will be presented. Details of crude glycerol conversion into microbial lipid and subsequent products will also be highlighted.
\end{abstract}

Keywords: glycerol; valorization; purification; oxidative fuel additives; biological conversion; animal feed

\section{Introduction}

Global energy demand will increase due to population growth, industrialization and humankind's desire for a better quality of life. However, due to the limited nature of fossil fuel resources, and environmental and climate issues associated with its use, development of renewable energy has become imperative [1,2]. Biodiesel is a renewable biofuel that has the additional advantage of having lower levels of emission of Green House Gases (GHG) like carbon dioxide. It can thus help in mitigation of climate change and improve energy security. Chemically, biodiesel is a methyl or ethyl ester of fatty acid and is usually produced by transesterification of vegetable oils or animal fats with short chain alcohols [3]. However, increase in biodiesel production can lead to increase in the costs of edible vegetable oil. This leads to a debate of fuel versus food. In order to address such issues, use of alternative resources such as oils from non-edible plants [4], microbial sources [5] and use of waste-cooking oil [6] have been studied and even implemented. Even though the cost of production of biodiesel is currently higher than fossil-based diesel, its production across the world has increased due to the environmental benefits associated with it. One of the possible ways to improve the biodiesel production capacity would be to reduce the production of waste by-products and valorize the waste generated.

During the transesterification process, 1 mole of triglyceride produces 3 moles of biodiesel (ester) and 1 mole of glycerol. On this basis, every batch of biodiesel produces approximately $10 \mathrm{wt} \%$ of glycerol. The produced glycerol contains various impurities and is known as crude glycerol. Impurities in crude glycerol includes mainly methanol, soap, free fatty acids and salt (inorganic salts residues 
from catalysts), unreacted mono-, di- and triglycerols and water [7]. Purification and refining of crude glycerol are carried out to different grades for pharmaceutical, food and cosmetic sectors. Purification techniques such as chemical pre-treatment, methanol removal, vacuum distillation, ion exchange, activated carbon and membrane separation technology are costly and hence are seldom economically feasible. The price of reformed glycerol is $40-50$ cents/lb., which is 5- to 10 -fold more than crude glycerol [8].

Many biodiesel producers have started treating crude glycerol as a waste rather than purifying it for commercial applications [9]. Crude oil is also directly used as an ingredient in animal feed [10]. While crude glycerol can seem like a liability for many biodiesel producers, from a biorefining point of view, it holds great potential for use as a starting material for value-added bio-chemicals. Such value-added chemicals can generate additional revenue for the existing biodiesel industries and make the process more sustainable. Valorization of crude glycerol will also help meet the circular bioeconomy guidelines by extending the value of every component in the chain as long as possible. Utilizing crude glycerol to produce commercially valuable compounds will simultaneously help to resolve the environmental issues associated with crude glycerol management [11,12].

Crude glycerol can serve as a low-cost and stable feedstock as the biodiesel market is estimated to have significant (42\%) annual growth [13]. The cost of crude glycerol, which depends on the type of biodiesel feedstock, production process and location, varies between 3-20 cents/lb. [8,14]. Due to the low cost and stable nature of crude glycerol, researchers are focusing on its chemical and biological conversion into value-added products such as bioplastic, microbial oil, etc. Most of these conversion processes are constrained by the negative effects of impurities in crude glycerol on the chemical reaction or the microbial strains used for bioconversion. The use of robust microbes and processes can help overcome these problems and make the use of partially-treated crude glycerol possible.

Various methods have been developed to minimize the residual impurity present in crude glycerol [15]. These include development of heterogeneous catalysts used for the conversion of triglycerides to biodiesel. Interestingly, recent developments in bioconversion of crude glycerol to various value-added products show that certain microbial strains could take advantage of impurities present in crude glycerol [16]. Therefore, both pure, partially purified and non-purified glycerol could play a significant role in "waste to value" scenarios. Though conversion of glycerol to value-added biochemicals and biofuels has been widely investigated, these techniques are not extensively commercialized as yet. In this review, we will discuss the nature of crude glycerol and ongoing research of its conversion to value-added products. Both chemical and biological routes of glycerol valorization will be presented. Details of crude glycerol conversion into microbial lipid and subsequent products will also be highlighted. Figure 1 . summarizes the routes for crude glycerol valorization.

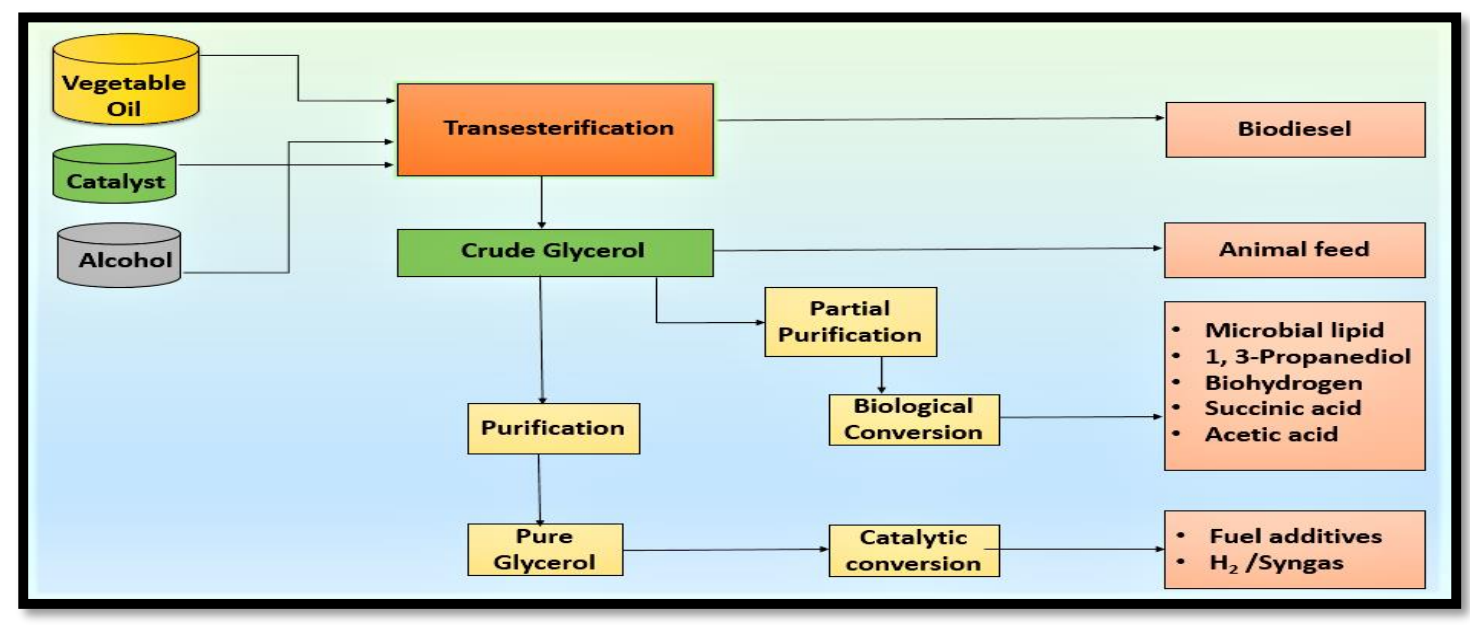

Figure 1. Crude glycerol valorization routes. 


\section{Impurities in Crude Glycerol and Hurdles to Use}

The composition of glycerol and level of impurities present in it depends on the type of vegetable oil, catalysts and alcohol used and process conditions etc. $[17,18]$. However, various impurities that are generally present in crude glycerol include un-reacted triglycerides and alcohol (commonly methanol), residual fatty acid methyl esters (FAMEs), water, soap, free fatty acids (FFA), salts and catalyst $[16,19,20]$. The type of catalyst used for biodiesel production plays a significant role in determining the type of impurities in crude glycerol. Use of homogeneous catalysts (such as sodium hydroxide) for biodiesel production results in the formation of higher levels of salts which eventually deposit into a crude glycerol layer. Lesser salts are formed when heterogeneous catalysts (e.g., calcium oxide) are used instead [19]. Additionally, homogeneous catalysts also lead to the generation of soap and gel, which leads to phase separation problems at the end of the biodiesel production process and during the conversion of crude glycerol into value-added products. Thus, to make the crude glycerol valorization process efficient and economically feasible, heterogeneous catalysts should be used, as they can result in glycerol with higher purity [15].

The end product of the transesterification processes comprises of two phases which differ in density and polarity. The upper phase is made up of biodiesel, while the lower phase is rich in crude glycerol and other impurities. The obtained crude glycerol must be purified further into technical or food grade for its commercial application. This purification of glycerol comprises a combination of both chemical and physical treatment. Generally, crude glycerol refining involves a three-step process. This starts with neutralization for the removal of soaps and salts followed by vacuum evaporation to eliminate the excess methanol and water. Finally, other unit operations are used to get purer form of glycerol. Neutralization of crude glycerol can be carried out by adding strong acids (such as sulfuric acid, phosphoric or hydrochloric acid) into crude glycerol. The acid converts the soap present in crude glycerol into free fatty acids. Strong acids like sulfuric acid, phosphoric acid and hydrochloric acid have been used for neutralization. In a second stage, alcohols are removed by vacuum distillation due to their lower boiling point. At commercial level, advanced heat transfer technologies, i.e., a falling film evaporator and rising film evaporator, ensure the prevention of glycerol decomposition [21]. Physical deep separation technologies like vacuum distillation, activated carbon adsorption, membrane separation and ion exchange chromatography have been employed in the final stage to obtain glycerol with higher purity [3,22]. Ismail et al. [23] refined glycerol using neutralization followed by microfiltration and ion exchange resin adsorption. Glycerol purity to a level of $86 \mathrm{wt} \%$ has been reported without a distillation operation [24]. A higher purity of $95.7 \mathrm{wt} \%$ was obtained by Manosak et al. [24] using acidification and polar solvent extraction followed by activated carbon adsorption. Commonly, vacuum distillation at higher temperature $\left(150-200{ }^{\circ} \mathrm{C}\right)$ must be employed to obtain technical grade glycerol $(99.5 \mathrm{wt} \%)$. In terms of process economy, thermal separation processes, i.e., distillation, accounts for $50 \%$ of plant operation costs due to its higher energy consumption. However, new distillation technologies using cyclic distillation columns and dividing wall column distillation (DWC) systems help process economy criteria without compromising the quality of the final product [25-27]. However, due to the slump in the price of glycerol, purification of crude glycerol to higher grade glycerol has become uneconomical. Due to this, crude glycerol is being treated as a waste by-product by various biodiesel producers. This has necessitated the conversion of crude glycerol into value-added products rather than purifying it into a higher grade.

A lot of research has been carried out to valorize crude glycerol. However, the impurities in crude glycerol have always deterred the success of such conversion processes. For instance, Payle et al. [28] reported that the presence of methanol impurities negatively affects the algal production of docosahexaenoic acid (DHA) from crude glycerol. Similarly, during biogas generation from crude glycerol via anaerobic co-digestion, impurities such as salts ( $\mathrm{Na}$ or $\mathrm{K}$ ) have been shown to inhibit the growth of microbes [29]. Shengjun Hu et al. [30] carried out a characterization of crude glycerol samples generated from a biodiesel production unit and reported that the crude glycerol was made up of eight components, namely, methanol, free glycerol, water, soap, fatty acids methyl esters, free fatty 
acids, glycerides and ash. The results show that $85 \%$ of the mass of crude glycerol is accounted for by glycerol, methanol, FAMEs, soap and water. On the other hand, glycerides, FFAs and ash make up less than $15 \%$.

\section{Technologies Studied for Value Addition of Glycerol}

\subsection{Chemo Catalytic Conversion}

Due to its unique structure, properties, availability and renewability, a number of value-added products can be derived from glycerol via catalytic transformation. Different reaction pathways, namely, selective oxidation, selective dehydration, reforming, thermal reduction and selective etherification, have been attempted for value addition of glycerol. The major catalyst-assisted, glycerol-derived production processes are discussed below.

\subsubsection{Oxidative Conversion of Glycerol to Fuel Additives}

Gasoline, diesel and biodiesel blended with fuel additives shows better performance due to important changes in fuel properties. It can also reduce the emission of greenhouse gases (GHG). Improvement in the fuel viscosity, octane and cetane number ensures stability, ease of cleanliness and prevention of engine corrosion [31-33]. Petroleum-derived fuel additives like ethanol, methyl tert-butyl ether (MTBE) and ethyl tert-butyl ether (ETBE) can be replaced with glycerol-derived additives, more specifically by glycerol esters, glycerol ethers and glycerol formals [34]. Major reactions for the production of fuel additives are acetylation [35-39] and ketalisation [40], in which glycerol interacts with chemical groups like carbonyl compounds [26].

\section{Glycerol Esters (Acetin)}

Esters of glycerol or acetin are produced using esterification with carboxylic acid in the presence of catalysts [32,33]. Acetylation of glycerol with acetic anhydride is also a potential route for the acetin synthesis [41,42]. Mono, di and tri acetin glycerol (MAG, DAG and TAG) are derived via a three-step esterification process of glycerol with acetic acid (Scheme 1) or acetic anhydride (Scheme 2). Mixed catalysts of $\mathrm{Zr}$ phosphate-sulphate and Amberlyst- 15 show the best catalytic performance in terms of complete conversion of glycerol and better selectivity of triacetin [35,43]. Information related to recent development of catalysts is presented in Table 1. Acetic anhydride is also a potential acetylating agent with higher selectivity of TAG due to the generation of an acetic acid molecule, which further reacts with the MAG and DAG produced in the first and second step, resulting in TAG [44]. Gonzalves et al. [35] reported the use of Amberlyst-15 as a catalyst for the esterification of glycerol with acetic acid. This resulted in excellent catalyst activity with $97 \%$ glycerol conversion and $90 \%$ selectivity of TAG obtained. Complete glycerol conversion is possible with $100 \%$ selectivity of TAG by performing the reaction in two steps: first, a reaction of glycerol with acetic acid and, second, a reaction with acetic anhydride [37]. Jinyan Sun et al. [45] prepared Fe-Sn-Ti $\left(\mathrm{SO}^{2-}{ }^{2-}\right)-400$ catalyst and tested it at $80^{\circ} \mathrm{C}$ for $30 \mathrm{~min}$ for glycerol esterification in the presence of acetic anhydride. It resulted in $99 \%$ selectivity of TAG with $100 \%$ conversion of glycerol.<smiles>OCC(O)CO</smiles>

Glycerol

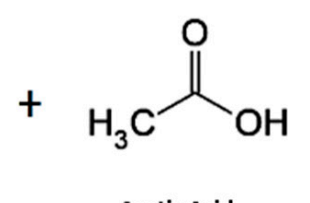

Acetic Acid

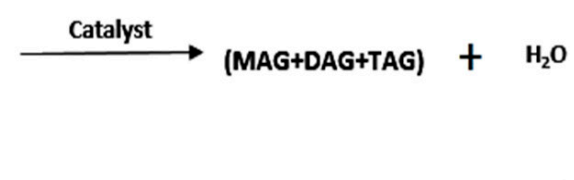

Scheme 1. Conversion of glycerol to acetin using carboxylic acids like acetic acid. 


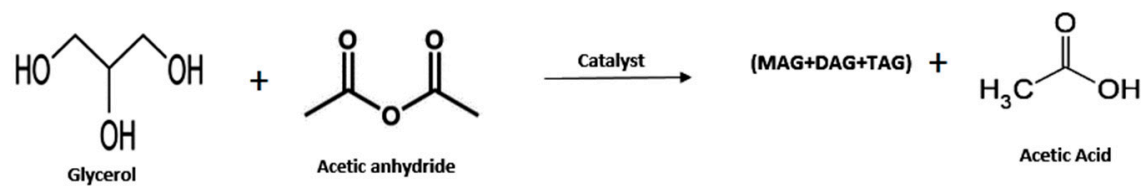

Scheme 2. Conversion of glycerol to acetin using acetic anhydride.

\section{Glycerol Ethers}

Highly branched materials can be derived via etherification of glycerol with alkenes (mainly isobutene) (Scheme 3) and alcohols like tert-butyl alcohol (TBA) (Scheme 4) in the presence of homogeneous or heterogeneous catalysts [35]. A blend of 1, 3-di, 1, 2-di and 1, 2, 3 tri-tert-butyl glycerol and aromatic diesel fuel drastically reduces the emission of particulate matter, hydrocarbons and carbon monoxide $[46,47]$. The low boiling point $\left(-6.9^{\circ} \mathrm{C}\right)$ of isobutene demands high pressure during the etherification reaction to keep it in a liquid stage for the reaction. Despite this, the reaction performance is governed by mass transfer between the two reactants [48]. However, the reaction conditions are mild with etherification of glycerol with TBA in the presence of an acid catalysts. In comparison with isobutene, TBA is more attractive for the production of glycerol tertiary butyl ethers (GTBEs) [49]. Behr and Obendorf [50] studied the reaction between isobutene and glycerol in the presence of p-toulene sulfonic acid and phosphorus tungstic acid. They observed low conversion of glycerol levels of $89 \%$ and $79 \%$, respectively, with these homogeneous catalysts. Huang and Kim [51] reported that that Amberlyst-15 exhibits the best efficiency with $97 \%$ conversion of glycerol and 33\% selectivity of TTBGs (tri-tert-butyl glycerol) and DTBGs with TBA. Amorphous carbon-based catalysts obtained using sulfonation of peanut shells shows very good catalytic performance, achieving complete glycerol conversion and $92 \%$ selectivity of GTBE at $70{ }^{\circ} \mathrm{C}$ [52]. The effectiveness of silica-based sulfonic catalyst that exhibits 78\% conversion of glycerol in $30 \mathrm{~min}$ of reaction time has also been reported [52].

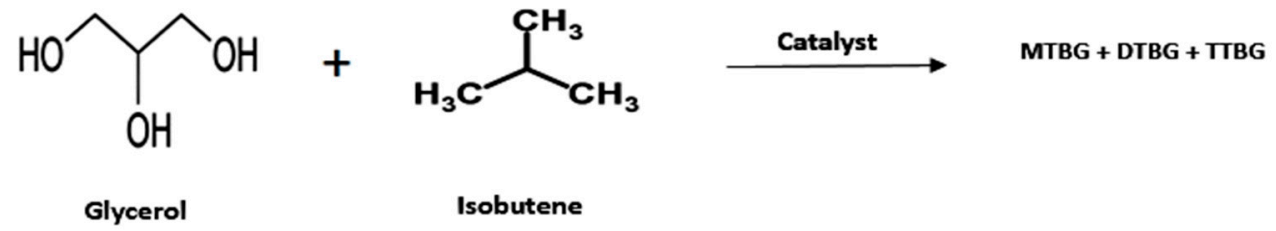

Scheme 3. Conversion of glycerol to glycerol ether using alkenes.

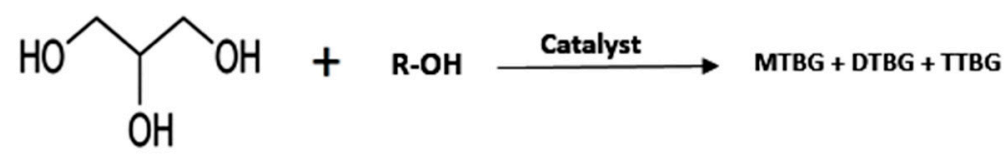

Glycerol

Scheme 4. Conversion of glycerol to glycerol ether using alcohols.

\section{Glycerol Formal}

Glycerol formal is a mixture of acetal and solketals and is derived via a condensation reaction of glycerol with aldehydes or ketones over homogeneous or heterogeneous catalysts (Scheme 5). The product composition of solketal and acetal is affected by reaction condition and type of catalyst [52,53]. Suriyaprapadilok and Kitiyanan [54] studied the reaction between glycerol and acetone in the presence of $\mathrm{p}$-toluene sulfonic acid. The results revealed that excess of acetone leads to higher levels of solketal, rather than acetals at the end of the $12 \mathrm{~h}$ reaction time. Malaya et al. [55] reported that Amberlyst-36 catalyst show good efficiency with $96 \%$ selectivity of solketal. Silva et al. [56] reported that longer aldehyde chains prevent its interaction with glycerol, and the pore size of the catalyst does not impact the conversion of acetone. More details about catalysts are summarized in Table 1 below. 


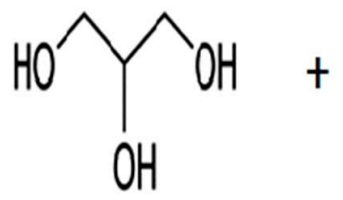

Glycerol<smiles>[R]C=O</smiles>

Aldehyde

Scheme 5. Conversion of glycerol to glycerol formal.

Table 1. Summary of reactants and catalysts used for oxidative fuel additives production.

\begin{tabular}{|c|c|c|c|c|c|c|}
\hline Entry & Reactant & Catalyst & Operating Condition & $\begin{array}{l}\text { \% Conv. } \\
\text { (glycerol) }\end{array}$ & $\begin{array}{c}\text { Yield } \\
(\%)\end{array}$ & Ref. \\
\hline 1 & Acetic acid & Catalyst Free & MR acetic acid to glycerol 6:1, $378 \mathrm{~K}, 4 \mathrm{~h}$ & 74 & $2^{1}$ & [37] \\
\hline 2 & Acetic acid & $\mathrm{Zr}_{3}\left(\mathrm{PO}_{4}\right)_{2}\left(\mathrm{SO}_{4}\right)_{3}$ & $\begin{array}{c}\text { Catalyst } 5 \mathrm{wt} \%, \text { MR acetic acid to } \\
\text { glycerol } 3: 1,105^{\circ} \mathrm{C}, 3 \mathrm{~h}\end{array}$ & 100 & $53^{1}$ & [43] \\
\hline 3 & Acetic acid & $\mathrm{Zr}_{4}\left(\mathrm{PO}_{4}\right)_{2}\left(\mathrm{SO}_{4}\right)_{5}$ & $\begin{array}{c}\text { Catalyst } 5 \mathrm{wt} \%, \mathrm{MR} \text { acetic acid to } \\
\text { glycerol } 3: 1,105^{\circ} \mathrm{C}, 3 \mathrm{~h}\end{array}$ & 100 & $48^{1}$ & [43] \\
\hline 4 & Acetic acid & $\mathrm{Zr}\left(\mathrm{SO}_{4}\right)_{2}$ & $\begin{array}{c}\text { Catalyst } 5 \mathrm{wt} \% \text {, MR acetic acid to } \\
\text { Glycerol } 3: 1,105^{\circ} \mathrm{C}, 3 \mathrm{~h}\end{array}$ & 60 & NA & [43] \\
\hline 5 & Acetic acid & Amberlyst- 15 & $\begin{array}{l}\text { Catalyst } 0.2 \mathrm{~mol} \% \text {, MR acetic acid to } \\
\text { glycerol 3:1, room temp, } 30 \mathrm{~min}\end{array}$ & 97 & $90^{1}$ & [35] \\
\hline 6 & Acetic acid & TAC-673 Catalyst & $\begin{array}{l}\text { Catalyst } 5 \mathrm{wt} \%, \text { MR acetic acid to } \\
\text { glycerol 9:1, } 378 \mathrm{~K}, 4 \mathrm{~h}\end{array}$ & $>99$ & $17^{1}$ & [57] \\
\hline 7 & Acetic anhydride & H-Beta zeolite & $\begin{array}{l}\text { Catalyst } 2.0 \mathrm{mmol} \text { acid sites, MR acetic a } \\
\text { hydride to glycerol } 4: 1,393 \mathrm{~K}, 2 \mathrm{~h}\end{array}$ & 94 & $43^{1}$ & [56] \\
\hline 8 & Acetic anhydride & $\begin{array}{c}\text { Fe-Sn-Ti } \\
\left(\mathrm{SO}^{2-}\right)-400\end{array}$ & $\begin{array}{l}\text { Catalyst } 0.05 \mathrm{~g} \text {, glycerol } 1.5 \mathrm{~g} \text {, acetic } \\
\text { anhydride } 8.39 \mathrm{~g}, 80^{\circ} \mathrm{C}, 30 \mathrm{~min}\end{array}$ & 100 & $99^{1}$ & [45] \\
\hline 9 & Acetic anhydride & Amberlyst-15 & $\begin{array}{l}\text { Catalyst } 0.05 \mathrm{~g} \text {, glycerol } 1.5 \mathrm{~g} \text {, acetic } \\
\text { anhydride } 8.39 \mathrm{~g}, 80^{\circ} \mathrm{C}, 30 \mathrm{~min}\end{array}$ & 99 & $99^{1}$ & {$[45]$} \\
\hline 10 & Acetic anhydride & HZSM-5 & $\begin{array}{l}\text { Catalyst } 0.05 \mathrm{~g} \text {, glycerol } 1.5 \mathrm{~g} \text {, acetic } \\
\text { anhydride } 8.39 \mathrm{~g}, 80^{\circ} \mathrm{C}, 30 \mathrm{~min}\end{array}$ & 99 & $24^{1}$ & {$[45]$} \\
\hline 11 & Tert Butyl alcohol (TBA) & Amberlyst-15 & $\begin{array}{c}\text { Catalyst } 7.5 \mathrm{wt} \% \text {, TBA/glycerol molar } \\
\text { ratio } 8,70^{\circ} \mathrm{C}, 5-8 \mathrm{~h}\end{array}$ & 97 & $30.3^{2}$ & [51] \\
\hline 12 & Tert Butyl alcohol (TBA) & $\mathrm{SiO}_{2}-\mathrm{SO}_{3} \mathrm{H}$ & $\begin{array}{c}\text { Catalyst } 5 \mathrm{wt} \% \text {, TBA/glycerol }= \\
2 \mathrm{~mol} / \mathrm{mol}, 30 \mathrm{~min}, 130^{\circ} \mathrm{C}\end{array}$ & 78 & $24^{2}$ & [58] \\
\hline 13 & Isobutene (IB) & $\begin{array}{l}\text { p-toluene } \\
\text { sulfonic acid }\end{array}$ & $\begin{array}{c}\text { Catalyst } 2.16 \mathrm{wt} \% \text {, IB } / \text { glycerol }= \\
4 \mathrm{~mol} / \mathrm{mol}, 5 \mathrm{~h}, 90^{\circ} \mathrm{C}, 1.4 \mathrm{bar}\end{array}$ & 89 & $47^{2}$ & {$[50]$} \\
\hline 14 & Isobutene (IB) & Amberlyst-15 & $\begin{array}{c}\text { Catalyst } 1 \mathrm{~g}, \mathrm{IB} / \text { glycerol }=4 \mathrm{~mol} / \mathrm{mol}, 7 \mathrm{~h}, \\
80^{\circ} \mathrm{C}, 15 \mathrm{bar}\end{array}$ & $>95$ & $97^{2}$ & [59] \\
\hline 15 & Isobutene (IB) & $\begin{array}{l}\text { Sulfonated } \\
\text { peanut shell }\end{array}$ & $\begin{array}{c}\text { Catalyst } 6 \mathrm{wt} \%, \mathrm{IB} / \text { glycerol }=4 \mathrm{~mol} / \mathrm{mol} \text {, } \\
2 \mathrm{~h}, 70^{\circ} \mathrm{C}, 15 \mathrm{bar}\end{array}$ & 100 & $92^{2}$ & {$[60]$} \\
\hline 16 & Acetone & Amberlyst-36 & $\begin{array}{l}\text { Acetone to glycerol ratio } 4: 1, \\
\qquad 25^{\circ} \mathrm{C}, 500 \mathrm{psi}\end{array}$ & 100 & $96^{3}$ & [55] \\
\hline 17 & Acetone & catalyst free & $\begin{array}{l}\text { Reaction at super critical condition, } \\
508 \mathrm{~K}, 8 \mathrm{MPa}, 240 \mathrm{~min}\end{array}$ & 28 & $80^{3}$ & {$[61]$} \\
\hline 18 & Acetone & $\mathrm{SnCl}_{2}$ & Catalyst: $1 \mathrm{wt} \%$, acetone/glycerol $=8: 1$ & 78 & $76^{3}$ & [62] \\
\hline 19 & Acetone & $\begin{array}{l}\text { DT- } 851 \text { sulfonic } \\
\text { acid resin }\end{array}$ & $\begin{array}{l}\text { Catalyst: } 5 \% \text {, acetone/glycerol: } 20: 1 \text {, } \\
\qquad 58{ }^{\circ} \mathrm{C}, 10 \mathrm{bar}\end{array}$ & 95 & $99^{3}$ & [63] \\
\hline 20 & Benzalde-hyde & $\begin{array}{l}\mathrm{K} 10 \\
\text { montmorillonite }\end{array}$ & Benzaldehyde/glycerol: 1.1:1, $40{ }^{\circ} \mathrm{C}, 6 \mathrm{~h}$ & 83 & $99^{3}$ & [63] \\
\hline
\end{tabular}

${ }^{1}$ Tri acetin glycerol, ${ }^{\text {NA }}$ not available, ${ }^{2}$ glycerol tertiary butyl ethers, ${ }^{3}$ solketal.

\subsubsection{Hydrogen or Syngas Production from Glycerol}

Hydrogen is a promising potential ecofriendly fuel as its combustion leads to the production of only water molecules as a by-product. Currently most hydrogen production processes $(95 \%)$ use fossil fuel as the raw material. Similarly, syngas, a mixture of hydrogen and carbon monoxide, is also considered as a valuable intermediate for the production of methanol and hydrocarbons through Fischer-Tropsch synthesis [64,65]. The production of hydrogen and syngas is another promising use of glycerol (Scheme 6). Conversion techniques like pyrolysis, steam reforming, partial oxidation, auto thermal reforming and aqueous phase reforming can be used for the production of hydrogen and syngas from glycerol. Pyrolysis of glycerol is a thermal decomposition process in the absence of oxygen. Glycerol is converted to hydroxyacetone, 3-hydroxypropenal and glyceraldehyde by dehydration and dehydrogenation reactions and then transformed into syngas at higher temperature [66]. Higher heat inputs and unstable product distribution facilitates glycerol pyrolysis [34]. Steam reforming, a combination of pyrolysis and a water gas shift reaction, is a common technology applied for hydrogen 
and syngas production from glycerol. Pre-vaporization of reactants demands higher heat input and process heat. However, the reaction is carried out at ambient condition of pressure $[67,68]$. Aqueous phase reforming, a process developed by Dumesic et al. [69], transforms glycerol in an aqueous phase without pre-vaporization under a moderate temperature (470-525 K) and pressure (16-40 bar). The automobile industry uses the high purity hydrogen synthesized by aqueous phase reforming for PEM fuel cells [70]. Partial oxidative reforming is an exothermic process in which glycerol conversion efficiency relies on controlling the amount of oxygen that enters into the reaction mixture. Partial oxidation reforming processes have high energy efficiency and also allow the production of syngas with control of the added amount of oxygen [71]. Supercritical water reforming is an innovative route for the production of hydrogen at higher pressure and lower temperature. Water takes part in the reaction at its critical point $\left(374^{\circ} \mathrm{C}, 218 \mathrm{~atm}\right)$ [72]. Table 2 includes a summary of the performance of some catalysts in the conversion of crude glycerol to hydrogen and syngas, as recently reported in the literature.

$$
\mathrm{C}_{3} \mathrm{H}_{8} \mathrm{O}_{3}+\mathrm{H}_{2} \mathrm{O}+\mathrm{O}_{2} \quad \stackrel{\text { Catalyst }}{\longrightarrow} \mathrm{CO}_{2}+\mathrm{CO}+\mathrm{H}_{2} \mathrm{O}+\mathrm{H}_{2}+\mathrm{CH}_{4}+\ldots
$$

Scheme 6. Conversion of glycerol to hydrogen and syngas.

Table 2. Review of literature on the conversion of glycerol to hydrogen and syngas.

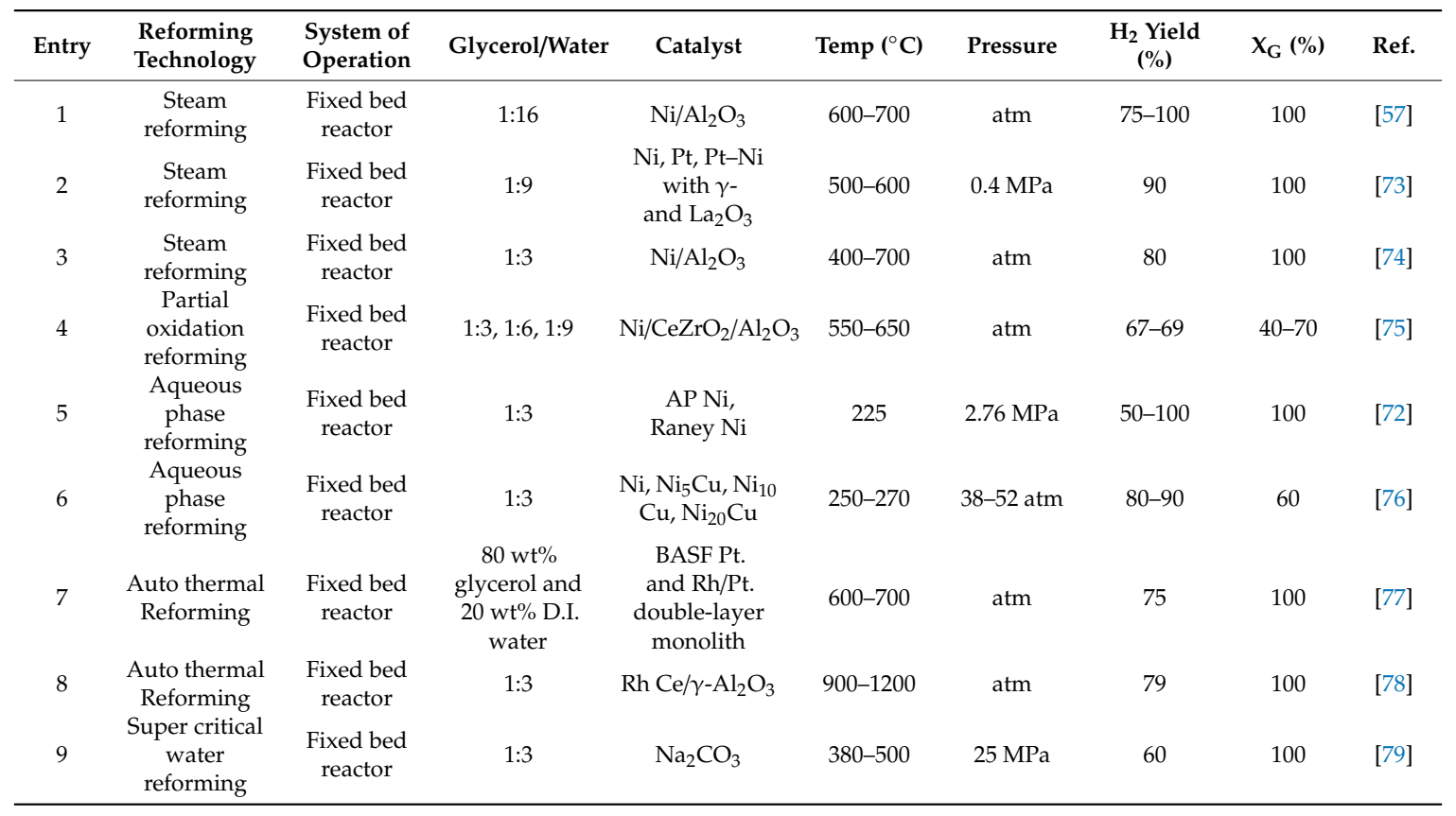

\subsection{Direct Use or Minimal Treatment Products}

Glycogenic amino acid and adipose triglycerides are valuable sources for glucose synthesis for animals that produce milk. Ketosis is a metabolic disorder that commonly takes place during the calving of an animal. Glycerol drenching is an effective treatment for the prevention of ketosis as the metabolic pathway of glycerol is pretty similar to glucose [80]. Cotrill et al. [81] reported high and rapid availability of net $(2.27 \mathrm{Mcal} / \mathrm{kg})$ and gross energy $(4.32 \mathrm{Mcal} / \mathrm{kg})$ from glycerol used as a lactation energy supplement. The possible use of glycerol as an animal food supplement depends on various parameters like the supply of glycerol, fuel demands and the price of the other feeds like oil seeds or fats which that are used for the production of biodiesel [82]. Bodarski et al. [83] showed that glycerol increases the blood insulin concentration in cows, which in turn improves the milk protein content and yield. In dairy cows, body weight (BW), body condition score (BCS), ruminal volatile fatty acids (VFA) and feed intake increases on glycerol administration in feed [10]. When added as feed to laying hens, egg quality, nutrient retention, metabolic energy and egg performance is unaffected 
by incorporation of $6 \%$ glycerol in their diet [84]. Growth performance and nutrient digestibility is not affected by increasing the glycerol intake level in broiler diets [85]. Hampy et al. [86] indicates that $5 \%$ crude glycerol in a meat goat's diet is beneficial. Presence of impurities in crude glycerol is an important consideration while using crude glycerol as an animal feed supplement as it directly affects nutritive value and health. Drackley [82] reported the effect of methanol impurities in glycerol on pre-ruminant calves. Energy rich grain such as corn could be replaced by glycerol after removing the impurities of methanol [87]. While use of crude glycerol in this manner is possible, the conversion of glycerol to value-added products could lead to higher benefits.

\subsection{Biological Conversion of Glycerol to Value-Added Chemicals}

Most of the chemical routes for conversion of glycerol to value-added products discussed above make use of harsh and toxic chemicals. On the one hand, exposure to such chemicals can be detrimental to individual health. On the other, release of effluents containing such chemicals can seriously impact the existing eco-system. Furthermore, chemical conversions are quite energy intensive [88,89]. Thus, biological conversion of glycerol into different useful chemicals and compounds has been extensively explored. Like other biological conversions, glycerol conversion via the biological route is gaining popularity due to its use of enzymes and microbes, which have practically no negative impact upon the human population and environment. Some of the conversion processes (reactions) which are generally complex and infeasible via the chemical route can also be accomplished easily by using biological routes. However, the main drawbacks of the bioconversion process are its costs due to low productivity $[90,91]$. As both the conversion processes (chemical or biological) have certain drawbacks, a combination of these conversion processes has also been explored in order to increase the productivity of the overall process $[92,93]$.

The carbon source which serves as the essential nutrient for microbes accounts for approximately $60 \%$ of the annual operation cost of fermentation systems. Thus, replacing the conventional carbon sources such as glucose with cheap substrates (e.g., crude glycerol, lignocellulose hydrolysate, effluents from pulp and paper industries, etc.) can reduce the overall production cost $[90,94,95]$. Use of such cheap substrates makes the biological conversion process economically feasible and sustainable. Additionally, from an environmental point of view, recycling of such waste by-products is desirable. Due to these reasons, crude glycerol has been extensively explored as an alternative carbon source for various biological conversion processes [96]. Glycerol also holds biochemical advantages over other sugars [97]. The amount of reducing equivalents produced from bioconversion of glycerol to pyruvate or phosphoenolpyruvate is twice more as compared with hexose and pentose [96,98].

Additionally, utilization of glycerol reduces concerns associated with the diauxic growth which often adversely affect the productivity of the conversion. For instance, when lignocellulosic hydrolysate/pre-hydrolysates are used as the carbon source for microbial growth, the microorganisms under study selectively consume preferred hexose sugars over the other types of sugar [97]. The problem of catabolic repression can be avoided by using glycerol. These characteristics of glycerol makes crude glycerol a potentially suitable substrate for its efficient biological conversion to commercially valuable products. Some of the important value-added biochemicals that have been studied for their production using crude glycerol via the biological route are discussed below.

\subsubsection{Microbial Lipids}

Microbial lipids, also known as single-cell oils (SCO), are obtained from a group of microbes known as oleaginous microorganisms. Oleaginous microbes are microorganisms that can accumulate lipids as more than $20 \%$ of their dried cell biomass. These microbes can fall into the categories of yeasts, fungus, bacteria or microalgae $[99,100]$. Most of the oleaginous yeasts and fungi (mainly molds) accumulate lipids in the range of $40 \%-70 \%[5,101,102]$. Lipid accumulation in microalgae can vary between $1 \%$ and $70 \%$ [103] with some of them capable of accumulating up to $90 \%$ under certain conditions [104]. Lipids in yeast, fungus and microalgae are mostly neutral lipids, mainly triglycerides (TAG). The lipid also 
contains free fatty acids, phospholipids, etc., but in much lower levels. Very few bacterial species can accumulate large quantities of lipids. Most of the lipids from bacteria are mostly complex lipoids such as polyhydroxyalkanoic acids (PHA). However, few bacterial strains belonging to the actinomycetes group seems to accumulate a high amount of lipids (up to $70 \%$ ). Additionally, unlike other bacteria, the lipids from actinomycetes genera are of the TAG form $[5,100,102]$. Lipid accumulation in oleaginous microorganisms takes places under stress environments, such as a shortage of major nutrients in the media. Under nutrient-limited conditions (usually nitrogen or phosphorus) and enough or excess amount of carbon sources, in oleaginous microbes (fungus and microalgae) the carbon flux is directed towards the accumulation of lipids $[100,105]$. Lipids obtained from oleaginous yeast, fungi and microalgae are in the form of neutral lipids and their fatty acids profiles are quite similar to the oils from plants and animals $[100,102]$. Thus, such lipids can potentially be used as an alternative to conventional oils in food, pharmaceutical and biofuel industries.

In recent decades, potential use of microbes to produce oils or oleo-chemical products is gaining popularity. This is because use of microbial lipids addresses some of the issues associated with the production of vegetable oils via a conventional route. Unlike conventional vegetable oil production, microbial lipid production does not make use of large amount of arable lands. In addition, the production process is less dependent on weather conditions, requires a lower amount of water and manpower, is easier to scale up and has a shorter life cycle compared to conventional vegetable oils $[16,106]$. Two types of microbial oil production pathways exist in oleaginous microbes: (i) the de novo pathway and (ii) ex novo pathway. Conventional sugar sources (such as glucose and glycerol) or organic acids present in the fermentation media are catabolized and converted into storage lipids via the de novo pathway.

Most of the hydrophobic compounds (e.g., fatty acids or oils) present in the media are taken up with the aid of active transport inside the microbial cell via the ex-novo pathway for growth or accumulation as lipids $[100,107,108]$. Compared to the ex- novo pathway, when microbial growth takes place on hydrophilic substrate, such as glycerol, lipids with higher quantities of triglycerides (TGA) are produced [109]. The biochemistry of lipid metabolism of oleaginous microbes differs from that of non-oleaginous microbes mainly in two ways. Firstly, in oleaginous microbes, citric acid is continuously converted to acetyl Coenzyme A (CoA) (a precursor for the fatty acid pathway) by adenosine triphosphate (ATP): citrase lyase (ACL).

Presence of such mechanism ensures the availability of enough precursor for the fatty acid biosynthesis. Secondly, nicotinamide adenine dinucleotide phosphate (NADPH; coenzyme), an essential reductant used in fatty acid biosynthesis, is generated sufficiently from malic acid or similar alternative NADPH-generating sources [100,109]. Generally, molds accumulate a large amount of lipids richer in polyunsaturated fatty acids (PUFA). Lipids with high levels of PUFAs such as gamma linoleic acid (GLA), eicosapentaenoic acid (EPA), arachidonic acid (ARA), and docosahexaenoic acid (DHA) have a number of health benefits and thus find a lot of food and medicine applications $[108,110]$.

Microbial lipids obtained from yeasts have a high amount of monounsaturated fatty acids (MUFA) and thus can be used as suitable feedstock to produce biodiesel. We have demonstrated the use of oils rich in MUFA for the production of other compounds such as bioplastics [16,93,111,112]. The chemical composition of lipids obtained from oleaginous microbes also depends on factors such as the type of species or strain, media composition and growth conditions. We also grew Rhodosporidium toruloides ATCC 10788 in media with different concentrations of essential oil from orange. Microbial oils with different fatty acids profiles were obtained. Similarly, growth parameters such as temperature also have a direct effect on the chemical composition of the lipids obtained [111,112]. When oleaginous yeast Lipomyces starkeyi was grown under different temperature conditions (i.e., $15^{\circ} \mathrm{C}$ to $28^{\circ} \mathrm{C}$ ), the lipids obtained were quite different in their fatty acids profiles. At a lower accumulation phase temperature ( 15 to $18{ }^{\circ} \mathrm{C}$ ), the lipids obtained had a higher degree of unsaturation compared to that at $28^{\circ} \mathrm{C}$ [113]. Though microbial lipids have a huge potential to replace conventional oils, they are currently still very expensive compared to vegetable oils. To make it cost competitive, cheap substrates, such as crude 
glycerol from biodiesel industries, should be used for their production [110]. This will significantly reduce the overall production cost of microbial lipids. Due to this reason, recent studies have focused on utilization of crude glycerol to produce microbial lipids. However, like in other bioconversion processes, impurities present in the crude glycerol have posed a huge problem for such conversion. Methanol, salt and soap are three major impurities that have been found to hinder the production of microbial oils from crude glycerol [114-117]. Pyle et al. [28] found that the presence of methanol and soap in crude glycerol reduces the biomass and DHA production of Schizochytrium limacinum SR-21. Similarly, Gao et al. [118] reported that methanol can significantly reduce the lipid production of oleaginous yeast Rhodosporidium toruloides 32489. Compared to the control experiment, the presence of methanol in the media reduced the lipid production by $17.7 \%$.

In another instance, salt $(5.5 \% \mathrm{NaCl})$ present in crude glycerol was found to have a detrimental effect on the growth and poly(3-hydroxybutyrate) (PHB) content (reduced by $48 \%$ ) of P. denitrificans [119]. It is due to these reasons that many researchers have focused on pre-treating crude glycerol before its utilization as a carbon substrate for the growth of these microbes. Purification of crude glycerol to a certain degree before its biological conversion requires an additional unit of operation in the overall production of microbial lipids. With the addition of such a unit of operation, the overall operational cost for the production of microbial lipids will increase. This will make conversion of crude glycerol to microbial oil production economically unattractive. Thus, from a commercial point of view, direct conversion of crude glycerol into microbial lipids is desirable. Thus, a robust strain that can withstand the harsh environment of crude glycerol has to be found. In this regard, we recently reported the robust oleaginous yeast, Rhodosporidium toruloides ATCC 10788, which grew well in crude glycerol with high levels of impurities [16].

When crude glycerol with $44.56 \mathrm{wt} \%$ glycerol, $13.86 \mathrm{wt} \%$ methanol, $10.74 \mathrm{wt} \%$ of ash and $32.97 \mathrm{wt} \%$ of soap was used as a carbon source for Rhodosporidium toruloides ATCC 10788, double the biomass $(21.16 \mathrm{~g} / \mathrm{L})$ and triple the lipid content $(11.27 \mathrm{~g} / \mathrm{L})$ were obtained. Similarly, oleaginous microorganisms such as Mortierella isabelline, Yarrowia lipolytica [120], Trichosporon fermentans CICC 1368 and Trichosporon cutaneum [121] have also been shown to grow well and accumulate lipids in the presence of impurities present in crude glycerol. In our lab, besides crude glycerol, we have also explored the potential use of hemicellulose hydrolysate, a waste by-product from a lignocellulose processing plant, as a cheap carbon substrate for the production of microbial lipid. The hemicellulose prehydrolysates from lignocellulosic biomass have similar issues with the presence of toxic compounds present in them. We reported that under optimum growth conditions, Cryptococcus curvatus ATCC 20509 can successfully grow in hemicellulose hydrolysate and produce $16.54 \mathrm{~g} / \mathrm{L}$ of cell biomass and $6.97 \mathrm{~g} / \mathrm{L}$ of lipid concentration at the end of $164 \mathrm{~h}$ without detoxification in a batch bioreactor [122].

\subsubsection{Constraints for the Commercial Production of Microbial Lipid from Crude Glycerol}

Even though various new approaches (screening robust screen, genetic modification, novel feeding strategies, pretreatment, etc.) have been explored for the valorization of waste by-products such as crude glycerol and lignocellulose hydrolysate, most of them have been limited to the research levels [100]. This is mainly because of variations in composition of these waste by-products, which have a direct impact on the bioconversion process. While this statement holds true in most of the biorefining processes, here we will limit our discussion to crude glycerol from biodiesel industries. The impurities present in crude glycerol are directly dependent on the type of substrate used for biodiesel production, production processes and the degree of downstream separation involved. All three factors vary considerably between industries and even between batches from the same production facility. A systematic study is required to determine the exact reason for such variations. There are also some additional reasons for these processes not to be easily scaled up to commercial levels. Currently, most of the biodiesel production processes are mainly designed focusing on the quantity and quality of biodiesel produced but overlook the quality of glycerol produced. To make the biodiesel more cost competitive and 
enhance the company's revenue, biodiesel producers often use cheaper feedstock, catalysts (such as sodium hydroxide) and downstream processes.

Cheaper feedstock used for biodiesel industries varies from plant-based oil to waste cooking oil. Most commonly, sodium hydroxide is used as a catalyst. While use of such feedstock and catalyst might help in the production of biodiesel that meets the specifications for commercial applications, the glycerol obtained is quite low in quality and even inconsistent from batch to batch. Such low-quality glycerol needs to be purified to a certain degree before use. However, due to the glut of glycerol, even purified glycerol prices have slumped [100]. Due to this, crude glycerol is currently treated as waste. Such waste glycerol has very few applications, and for its bioconversion, we need its composition to be consistent throughout. This leaves biodiesel producers in a dilemma of using improved biodiesel processes which would be costly or sticking to the conventional process and treat glycerol as waste. In this regard, we recently reported a comparative study between different types of biodiesel production catalysts.

We also provided a recommendation on what type of catalyst to use if a company wants to reduce the generation of crude glycerol waste without compromising on their current biodiesel production cost [15]. We found that even though the use of homogeneous catalyst (such as sodium hydroxide) can generate biodiesel that meets the commercial specification, it can generate low grade glycerol. To generate high quality biodiesel and glycerol, we recommended the use of a heterogeneous catalyst in an anchored or unanchored form. Use of such heterogeneous catalyst can produce commercial grade biodiesel and simultaneously a purer form of glycerol for its direct bioconversion into the value-added products. Integration of such a production process into existing biodiesel production plants can reduce the generation of glycerol waste and improve a company's revenue. To address the cost constraints involved with the use of heterogeneous catalyst, we have also demonstrated the potential use of ash as heterogeneous catalyst for biodiesel production. Even though biodiesel a production process simultaneously focusing on the quality of glycerol for its valorization and subsequently the revenue generation of a company is recommended, it will take a while before this is implemented by biodiesel producers. A major constraint to research in the use of crude glycerol valorization is the use of samples from a single batch. Such samples cannot be good enough to represent crude glycerol whose composition varies from batch to batch in real case scenarios. With so much variation in the composition of crude glycerol, it is even hard to prepare a representative synthetic crude glycerol in the lab to conduct any research. Hence, a comprehensive investigation of the effect of impurities and their interactions has to be carried out to overcome the stated constraints.

\subsubsection{Production of 1, 3-Propanediol}

1, 3-Propanediol (1, 3-PD) is perhaps the most investigated biochemical via bioconversion of glycerol. 1, 3-PD is a colorless viscous liquid belonging to the group of diols. It is one of the main precursors in the synthesis of polytrimethylene terephthalate (PTT) and other polymers. Furthermore, it has a variety of applications in cosmetics, foods, lubricants, and medicines [123,124]. Bacteria of the genera clostridium, klebsiella, citrobacter, hafnia, and lactobacillus are mainly reported for production of 1,3-PD from glycerol [123,125,126]. Among these, Clostridium butyricum and Klebsiella pneumoniae are well-studied bacteria. Even though Klebsiella pneumoniae produces a high level of 1, 3-PD, Clostridium strains such as C. butyricum and C. pasteurianum have attracted more attention as they are non-pathogenic and also have a vitamin B12 independent glycerol dehydratase enzyme, as opposed to Klebsiella pneumoniae, which is a pathogen and requires medium with exogenously-provided B12 $[127,128]$.

Bioconversion of glycerol to 1, 3-PD takes place in a two-step enzymatic reaction sequence. Firstly, glycerol is converted to 3 hydroxypropionaldehyde (3-HPA) and water by glycerol dehydratase, and then, NADH dependent 1, 3-PD dehydrogenase reduces 3 hydroxypropionaldehyde to 1, 3-PD [129]. Both pure and crude glycerol were compared for the production of 1,3-PD. In general, higher yields for production of not only 1, 3-PD but also other metabolites were reported with pure glycerol $[129,130]$. 
However, reports are available that show approximately the same yield from 1, 3-PD production for both pure as well as non-purified glycerol. For instance, $11.3 \mathrm{~g} / \mathrm{L}$ of 1, 3-PD was obtained using C. butyricum grown on both pure glycerol (99\%) and crude glycerol $(81.0 \%)$ during batch cultures in a 3-L bioreactor [131]. A positive influence of impurities has even been reported. Productivity of $1.51 \mathrm{~g} / \mathrm{L}$ $\mathrm{h}$ using crude glycerol as compared with $0.84 \mathrm{~g} / \mathrm{L} \mathrm{h}$ with pure glycerol was reported by Jun et al. [132] after $47 \mathrm{~h}$ of fermentation using Klebsiella pneumoniae.

\subsubsection{Microbial Hydrogen Production}

Hydrogen $\left(\mathrm{H}_{2}\right)$ is a clean and renewable fuel that produces only water on combustion. This can significantly reduce CO2, NOx, particulate and other emissions. Hydrogen not only serves as a clean fuel, but it is a valuable feedstock for production of food, pharmaceuticals, specialty chemicals and petrochemical products [133]. Four groups of microorganisms including anaerobic, facultative anaerobic, aerobic and phototrophic are involved in the production of hydrogen based on the biosynthesis pathways. The main fermentative bacteria known to produce hydrogen include Enterobacter sp., Bacillus sp., Clostridium sp., Klebsiella sp. and Citrobacter sp. [134]. Dark fermentation, photo fermentation, microbial electrolysis cells (MECs) and microbial fuel cells (MFCs) and combined methods were applied using glycerol as substrate for production of biohydrogen $[8,13]$. Dark fermentation showed better performance in terms of production rate, yield and cost as compared with $\mathrm{H}_{2}$ production usingt photosynthetic techniques. The cost of $\mathrm{H}_{2}$ production via the photosynthetic pathway is 300-fold higher than fermentative $\mathrm{H}_{2}$ production [135]. Microorganisms such as Clostridium sp. and Klebsiella pneumoniae $[136,137]$ in dark fermentation and Rhodopseudomonas palustris [138] in photosynthetic fermentation were used. A combination of dark fermentation with a MEC was studied using glycerol, and a maximum $\mathrm{H}_{2}$ rate of $332 \mathrm{~mL} / \mathrm{L}$ and a yield of $0.55 \mathrm{~mol} \mathrm{H}_{2} / \mathrm{mol}$ glycerol was achieved [139].

\subsubsection{Succinic Acid}

Succinic acid (SA) is a C4 linear saturated dicarboxylic acid and as a platform chemical plays a significant role in the synthesis of polymers such as polyesters and polyurethane. Furthermore, it has several applications in food, cosmetics and pharmaceuticals [140]. In 2018, the global production of (SA) was 131.71 million tones, and it is predicted that its market will increase further [141]. Production of SA on an industrial scale is based on the oxidation of maleic anhydride [142]. The high cost of this chemical conversion has motivated scientists to seek alternative economical processes. SA can be produced using microbial fermentation and a low-cost substrate such as glycerol, which will help to reduce the cost of production substantially. Moreover, biological conversion of SA requires the addition of $\mathrm{CO} 2$ to the culture broth, which contributes to the reduction of $\mathrm{CO} 2$ emissions [143].

Anaerobic facultative bacteria like Mannheimia succiniciproducens [144], Anaerobiospirillum succiniciproducens [145], Actinobacillus succinogenes [146] or Basfia succiniciproducens DD1 [147] have been reported to produce SA as a fermentation end-product. Engineered strains such as Yarrowia lipolytica [148] and Escherichia coli [149] have also been reported. Anaerobiospirillum succinici is one of the best SA producers, with production of $19 \mathrm{~g} / \mathrm{L}$ of succinate using glycerol as the only carbon source in the medium [150]. One of the limiting factors to achieving a higher yield is the redox imbalance during cell growth. Utilization of an external electron acceptor such as dimethylsulfoxide can improve the SA production in this strain [151].

\subsubsection{Citric Acid}

Citric acid is an organic acid with various applications, mainly in the food industry and pharmaceutical industry. Several microorganisms including bacteria, fungi and yeasts have been studied for the production of citric acid. Aspergillus niger has been used on an industrial scale [152] for microbial production of citric acid for a long time. Among citric acid producers, yeasts showed better resistance against metal ions which facilitate the use of non-pure substrate such as crude glycerol. 
This in turn improves the overall economy of the process [152]. In addition, the unicellular nature of yeast allows a better process control [153,154]. Candida (Yarrowia) lipolytica, Candida guilliermondii, Candida oleophila, Candida intermedia, Candida paratropicalis, Candida zeylanoides, Candida catenulata, Candida parapsilosis and Pichia anomala are the yeast species that were reported to produce citric acid $[155,156]$. Mutant strains of Yarrowia lipolytica were also reported to increase the production on glycerol [157]. It is a potential citric acid producer using this cheap substrate. Submerged fermentation in batch mode is the most common technique for this bioconversion [156].

\section{Conclusions}

The biodiesel industry is increasing globally, however, the economics aspect of this production remains a challenge. The fluctuation of the crude oil industry also affects the competitive price of biodiesel and other biofuels. Utilizing the desired by-product of biodiesel, glycerol, can contribute to the sustainable growth and economics of this high demand biofuel. Finding markets for crude glycerol will also address the environmental issues associated with the surplus generation of glycerol with expected growth of biodiesel production. We have attempted to highlight and evaluate various facets of glycerol valorization, ranging from crude glycerol composition, its purification and multiple routes of and the importance of taking into account glycerol purity when designing biodiesel plants. Glycerol esters, glycerol ether, glycerol formal, fuel additives and syngas can be obtained by chemical modification of glycerol. In addition, the reduced nature of carbon atoms in glycerol makes this low-cost substrate more attractive as compared with more oxidized carbon sources for biological conversion of glycerol to value-added biochemicals such as microbial lipid, 1, 3-propanediol, microbial hydrogen, succinic acid and citric acid. Both native and engineered microorganisms were able to consume pure as well as crude glycerol efficiently. In general, the high potential of using glycerol generated by the biodiesel industry needs to be harnessed as it will bring about economic and environmental benefits locally and globally. This in turn will help to move towards a circular bioeconomy.

Funding: The Canada Research Chair program and Canada Foundation for Innovation. (Grant Number 226965). Acknowledgments: Lakehead University.

Conflicts of Interest: The authors declare no conflict of interest.

\section{References}

1. Inglesi-Lotz, R. The impact of renewable energy consumption to economic growth: A panel data application. Energy Econ. 2016, 53, 58-63. [CrossRef]

2. Panwar, N.L.; Kaushik, S.C.; Kothari, S. Role of renewable energy sources in environmental protection: A review. Renew. Sustain. Energy Rev. 2011, 15, 1513-1524. [CrossRef]

3. Van Gerpen, J. Biodiesel processing and production. Fuel Process. Technol. 2005, 86, 1097-1107. [CrossRef]

4. Yousuf, A. Biodiesel from lignocellulosic biomass-Prospects and challenges. Waste Manag. 2012, 32, 2061-2067. [CrossRef]

5. Cho, H.U.; Park, J.M. Biodiesel production by various oleaginous microorganisms from organic wastes. Bioresour. Technol. 2018, 256, 502-508. [CrossRef] [PubMed]

6. Yaakob, Z.; Mohammad, M.; Alherbawi, M.; Alam, Z.; Sopian, K. Overview of the production of biodiesel from waste cooking oil. Renew. Sustain. Energy Rev. 2013, 18, 184-193. [CrossRef]

7. Pagliaro, M.; Rossi, M. Glycerol: Properties and production. In Future Glycerol; Royal Society of Chemistry's: Cambridge, UK, 2010; pp. 20-21.

8. Trchounian, K.; Trchounian, A. Hydrogen production from glycerol by Escherichia coli and other bacteria: An overview and perspectives. Appl. Energy 2015, 156, 174-184. [CrossRef]

9. Bohon, M.D.; Metzger, B.A.; Linak, W.P.; King, C.J.; Roberts, W.L. Glycerol combustion and emissions. Proc. Combust. Inst. 2011, 33, 2717-2724. [CrossRef]

10. Wang, C.; Liu, Q.; Yang, W.Z.; Huo, W.J.; Dong, K.H.; Huang, Y.X.; Yang, X.M.; He, D.C. Effects of glycerol on lactation performance, energy balance and metabolites in early lactation Holstein dairy cows. Anim. Feed Sci. Technol. 2009, 151, 12-20. [CrossRef] 
11. Luo, X.; Ge, X.; Cui, S.; Li, Y. Value-added processing of crude glycerol into chemicals and polymers. Bioresour. Technol. 2016, 215, 144-154. [CrossRef]

12. Yang, F.; Hanna, M.A.; Sun, R. Value-added uses for crude glycerol-a byproduct of biodiesel production. Biotechnol. Biofuels 2012, 5, 13. [CrossRef]

13. Garlapati, V.K.; Shankar, U.; Budhiraja, A. Bioconversion technologies of crude glycerol to value added industrial products. Biotechnol. Rep. (Amst.) 2016, 9, 9-14. [CrossRef]

14. Khanna, S.; Goyal, A.; Moholkar, V.S. Microbial conversion of glycerol: Present status and future prospects. Crit. Rev. Biotechnol. 2012, 32, 235-262. [CrossRef]

15. Uprety, B.K.; Chaiwong, W.; Ewelike, C.; Rakshit, S.K. Biodiesel production using heterogeneous catalysts including wood ash and the importance of enhancing byproduct glycerol purity. Energy Convers. Manag. 2016, 115, 191-199. [CrossRef]

16. Uprety, B.K.; Dalli, S.S.; Rakshit, S.K. Bioconversion of crude glycerol to microbial lipid using a robust oleaginous yeast Rhodosporidium toruloides ATCC 10788 capable of growing in the presence of impurities. Energy Convers. Manag. 2017, 135, 117-128. [CrossRef]

17. Thompson, J.C.; He, B.B. Characterization of crude glycerol from biodiesel production from multiple feedstocks. Appl. Eng. Agric. 2006, 22, 261-265. [CrossRef]

18. Hansen, C.F.; Hernandez, A.; Mullan, B.P.; Moore, K.; Trezona-Murray, M.; King, R.H.; Pluske, J.R. A chemical analysis of samples of crude glycerol from the production of biodiesel in Australia, and the effects of feeding crude glycerol to growing-finishing pigs on performance, plasma metabolites and meat quality at slaughter. Anim. Prod. Sci. 2009, 49, 154-161. [CrossRef]

19. Tan, H.W.; Aziz, A.R.A.; Aroua, M.K. Glycerol production and its applications as a raw material: A review. Renew. Sustain. Energy Rev. 2013, 27, 118-127. [CrossRef]

20. Kumar, L.R.; Yellapu, S.K.; Tyagi, R.D.; Zhang, X. A review on variation in crude glycerol composition, bio-valorization of crude and purified glycerol as carbon source for lipid production. Bioresour. Technol. 2019, 293, 122155. [CrossRef]

21. Rodrigues, A.; Bordado, J.C.; Santos, R.G.D. Upgrading the glycerol from biodiesel production as a source of energy carriers and chemicals-A technological review for three chemical pathways. Energies 2017, 10, 1817. [CrossRef]

22. Javani, A.; Hasheminejad, M.; Tahvildari, K.; Tabatabaei, M. High quality potassium phosphate production through step-by-step glycerol purification: A strategy to economize biodiesel production. Bioresour. Technol. 2012, 104, 788-790. [CrossRef] [PubMed]

23. Isahak, W.; Ismail, M.; Yarmo, M.A.; Jahim, J.M.; Salimon, J. Purification of crude glycerol from transesterification RBD palm oil over homogeneous and heterogeneous catalysts for the biolubricant preparation. J. Appl. Sci. (Faisalabad) 2010, 10, 2590-2595. [CrossRef]

24. Manosak, R.; Limpattayanate, S.; Hunsom, M. Sequential-refining of crude glycerol derived from waste used-oil methyl ester plant via a combined process of chemical and adsorption. Fuel Process. Technol. 2011, 92, 92-99. [CrossRef]

25. Maleta, V.N.; Kiss, A.A.; Taran, V.M.; Maleta, B.V. Understanding process intensification in cyclic distillation systems. Chem. Eng. Process. Process Intensif. 2011, 50, 655-664. [CrossRef]

26. Maleta, B.V.; Shevchenko, A.; Bedryk, O.; Kiss, A.A. Pilot-scale studies of process intensification by cyclic distillation. AIChE J. 2015, 61, 2581-2591. [CrossRef]

27. Kiss, A.A.; Ignat, R.M. Enhanced methanol recovery and glycerol separation in biodiesel production-DWC makes it happen. Appl. Energy 2012, 99, 146-153. [CrossRef]

28. Pyle, D.J.; Garcia, R.A.; Wen, Z. Producing docosahexaenoic acid (DHA)-rich algae from biodiesel-derived crude glycerol: Effects of impurities on DHA production and algal biomass composition. J. Agric. Food Chem. 2008, 56, 3933-3939. [CrossRef]

29. Santibáñez, C.; Varnero, M.T.; Bustamante, M. Residual glycerol from biodiesel manufacturing, waste or potential source of bioenergy: A review. Chil. J. Agric. Res. 2011, 71, 469-475. [CrossRef]

30. Hu, S.; Luo, X.; Wan, C.; Li, Y. Characterization of crude glycerol from biodiesel plants. J. Agric. Food Chem. 2012, 60, 5915-5921. [CrossRef]

31. Nda-Umar, U.I.; Ramli, I.; Taufiq-Yap, Y.H.; Muhamad, E.N. An overview of recent research in the conversion of glycerol into biofuels, fuel additives and other bio-based chemicals. Catalysts 2019, 9, 15. [CrossRef] 
32. García, J.I.; García-Marín, H.; Pires, E. Glycerol based solvents: Synthesis, properties and applications. Green Chem. 2014, 16, 1007-1033. [CrossRef]

33. Rahmat, N.; Abdullah, A.Z.; Mohamed, A.R. Recent progress on innovative and potential technologies for glycerol transformation into fuel additives: A critical review. Renew. Sustain. Energy Rev. 2010, 14, 987-1000. [CrossRef]

34. Farinha, J.; Caiado, M.; Castanheiro, J. Valorisation of Glycerol into Biofuel Additives over Heterogeneous Catalysts; Formatex Research Center: Badajoz, Spain, 2013.

35. Gonçalves, V.L.; Pinto, B.P.; Silva, J.C.; Mota, C.J. Acetylation of glycerol catalyzed by different solid acids. Catal. Today 2008, 133, 673-677. [CrossRef]

36. Dosuna-Rodríguez, I.; Gaigneaux, E.M. Glycerol acetylation catalysed by ion exchange resins. Catal. Today 2012, 195, 14-21. [CrossRef]

37. Liao, X.; Zhu, Y.; Wang, S.-G.; Li, Y. Producing triacetylglycerol with glycerol by two steps: Esterification and acetylation. Fuel Process. Technol. 2009, 90, 988-993. [CrossRef]

38. Zhou, L.; Nguyen, T.-H.; Adesina, A.A. The acetylation of glycerol over amberlyst-15: Kinetic and product distribution. Fuel Process. Technol. 2012, 104, 310-318. [CrossRef]

39. Balaraju, M.; Nikhitha, P.; Jagadeeswaraiah, K.; Srilatha, K.; Prasad, P.S.S.; Lingaiah, N. Acetylation of glycerol to synthesize bioadditives over niobic acid supported tungstophosphoric acid catalysts. Fuel Process. Technol. 2010, 91, 249-253. [CrossRef]

40. Di Serio, M.; Casale, L.; Tesser, R.; Santacesaria, E. New process for the production of glycerol tert-butyl ethers. Energy Fuels 2010, 24, 4668-4672. [CrossRef]

41. Usai, E.; Gualdi, E.; Solinas, V.; Battistel, E. Simultaneous enzymatic synthesis of FAME and triacetyl glycerol from triglycerides and methyl acetate. Bioresour. Technol. 2010, 101, 7707-7712. [CrossRef]

42. Morales, G.; Paniagua, M.; Melero, J.A.; Vicente, G.; Ochoa, C. Sulfonic acid-functionalized catalysts for the valorization of glycerol via transesterification with methyl acetate. Ind. Eng. Chem. Res. 2011, 50, 5898-5906. [CrossRef]

43. Testa, M.L.; La Parola, V.; Mesrar, F.; Ouanji, F.; Kacimi, M.; Ziyad, M.; Liotta, L.F. Use of Zirconium Phosphate-Sulphate as Acid Catalyst for Synthesis of Glycerol-Based Fuel Additives. Catalysts 2019, 9, 148. [CrossRef]

44. Sánchez, J.A.; Hernández, D.L.; Moreno, J.A.; Mondragón, F.; Fernández, J.J. Alternative carbon based acid catalyst for selective esterification of glycerol to acetylglycerols. Appl. Catal. A Gen. 2011, 405, 55-60. [CrossRef]

45. Sun, J.; Tong, X.; Yu, L.; Wan, J. An efficient and sustainable production of triacetin from the acetylation of glycerol using magnetic solid acid catalysts under mild conditions. Catal. Today 2016, 264, 115-122. [CrossRef]

46. Cornejo, A.; Barrio, I.; Campoy, M.; Lázaro, J.; Navarrete, B. Oxygenated fuel additives from glycerol valorization. Main production pathways and effects on fuel properties and engine performance: A critical review. Renew. Sustain. Energy Rev. 2017, 79, 1400-1413. [CrossRef]

47. Behr, A.; Eilting, J.; Irawadi, K.; Leschinski, J.; Lindner, F. Improved utilisation of renewable resources: New important derivatives of glycerol. Green Chem. 2008, 10, 13-30. [CrossRef]

48. Jaecker-Voirol, A.; Durand, I.; Hillion, G.; Delfort, B.; Montagne, X. Glycerin for new biodiesel formulation. Oil Gas Sci. Technol. Rev. IFP 2008, 63, 395-404. [CrossRef]

49. Mangourilos, V.; Bombos, D.; Juganaru, T.; Bolocan, I.; Bombos, M.; Ciuparu, D. Etherification of glycerol with isobutene on Amberlyst 35 ion exchange resin catalyst in presence of a cationic emulsifier. Rev. Chim. 2009, 60, 1338-1342.

50. Behr, A.; Obendorf, L. Development of a process for the acid-catalyzed etherification of glycerine and isobutene forming glycerine tertiary butyl ethers. Eng. Life Sci. 2002, 2, 185-189. [CrossRef]

51. Huang, R.; Kim, E.Y. Catalytic synthesis of glycerol tert-butyl ethers as fuel additives from the biodiesel by-product glycerol. J. Chem. 2015, 2015. [CrossRef]

52. Maksimov, A.L.; Nekhaev, A.I.; Ramazanov, D.N.; Arinicheva, Y.A.; Dzyubenko, A.A.; Khadzhiev, S.N. Preparation of high-octane oxygenate fuel components from plant-derived polyols. Pet. Chem. 2011, 51, 61-69. [CrossRef]

53. Mota, C.J.A.; da Silva, C.X.A.; Rosenbach Jr, N.; Costa, J.; da Silva, F. Glycerin derivatives as fuel additives: The addition of glycerol/acetone ketal (solketal) in gasolines. Energy Fuels 2010, 24, 2733-2736. [CrossRef] 
54. Suriyaprapadilok, N.; Kitiyanan, B. Synthesis of solketal from glycerol and its reaction with benzyl alcohol. Energy Procedia 2011, 9, 63-69. [CrossRef]

55. Nanda, M.R.; Zhang, Y.; Yuan, Z.; Qin, W.; Ghaziaskar, H.S.; Xu, C.C. Catalytic conversion of glycerol for sustainable production of solketal as a fuel additive: A review. Renew. Sustain. Energy Rev. 2016, 56, 1022-1031. [CrossRef]

56. Silva, P.H.R.; Gonçalves, V.L.C.; Mota, C.J.A. Glycerol acetals as anti-freezing additives for biodiesel. Bioresour. Technol. 2010, 101, 6225-6229. [CrossRef] [PubMed]

57. Sánchez, E.A.; D’Angelo, M.A.; Comelli, R.A. Hydrogen production from glycerol on Ni/Al2O3 catalyst. Int. J. Hydrog. Energy 2010, 35, 5902-5907. [CrossRef]

58. Aguado-Deblas, L.; Estevez, R.; Russo, M.; La Parola, V.; Bautista, F.M.; Testa, M.L. Microwave-Assisted Glycerol Etherification Over Sulfonic Acid Catalysts. Materials 2020, 13, 1584. [CrossRef]

59. Karinen, R.S.; Krause, A.O.I. New biocomponents from glycerol. Appl. Catal. A Gen. 2006, 306, 128-133. [CrossRef]

60. Zhao, W.; Yang, B.; Yi, C.; Lei, Z.; Xu, J. Etherification of glycerol with isobutylene to produce oxygenate additive using sulfonated peanut shell catalyst. Ind. Eng. Chem. Res. 2010, 49, 12399-12404. [CrossRef]

61. Royon, D.; Locatelli, S.; Gonzo, E.E. Ketalization of glycerol to solketal in supercritical acetone. J. Supercrit. Fluids 2011, 58, 88-92. [CrossRef]

62. Da Silva, M.J.; de Oliveira Guimaraes, M.; Julio, A.A. A highly regioselective and solvent-free Sn (II)-catalyzed glycerol ketals synthesis at room temperature. Catal. Lett. 2015, 145, 769-776. [CrossRef]

63. Yang, J.; Li, N.; Ma, W.J.; Zhou, J.H.; Sun, H.Z. Synthesis of Solketal with Catalyst Sulfonic Acid Resin; Trans Tech Publications Ltd.: Stafa-Zurich, Switzerland, 2014; pp. 176-179.

64. Avasthi, K.S.; Reddy, R.N.; Patel, S. Challenges in the production of hydrogen from glycerol-A biodiesel byproduct via steam reforming process. Procedia Eng. 2013, 51, 423-429. [CrossRef]

65. Adhikari, S.; Fernando, S.D.; Haryanto, A. Hydrogen production from glycerin by steam reforming over nickel catalysts. Renew. Energy 2008, 33, 1097-1100. [CrossRef]

66. Wang, W. Thermodynamic analysis of glycerol partial oxidation for hydrogen production. Fuel Process. Technol. 2010, 91, 1401-1408. [CrossRef]

67. Vaidya, P.D.; Rodrigues, A.E. Glycerol reforming for hydrogen production: A review. Chem. Eng. Technol. Ind. Chem. Plant Equip. Proc. Eng. Biotechnol. 2009, 32, 1463-1469. [CrossRef]

68. Luo, N.; Zhao, X.; Cao, F.; Xiao, T.; Fang, D. Thermodynamic study on hydrogen generation from different glycerol reforming processes. Energy Fuels 2007, 21, 3505-3512. [CrossRef]

69. Huber, G.W.; Cortright, R.D.; Dumesic, J.A. Renewable alkanes by aqueous-phase reforming of biomass-derived oxygenates. Angew. Chem. Int. Ed. 2004, 43, 1549-1551. [CrossRef]

70. Davda, R.R.; Shabaker, J.W.; Huber, G.W.; Cortright, R.D.; Dumesic, J.A. A review of catalytic issues and process conditions for renewable hydrogen and alkanes by aqueous-phase reforming of oxygenated hydrocarbons over supported metal catalysts. Appl. Catal. B Environ. 2005, 56, 171-186. [CrossRef]

71. Lin, Y.-C. Catalytic valorization of glycerol to hydrogen and syngas. Int. J. Hydrog. Energy 2013, 38, 2678-2700. [CrossRef]

72. Guo, Y.; Liu, X.; Azmat, M.U.; Xu, W.; Ren, J.; Wang, Y.; Lu, G. Hydrogen production by aqueous-phase reforming of glycerol over Ni-B catalysts. Int. J. Hydrog. Energy 2012, 37, 227-234. [CrossRef]

73. Iriondo, A.; Cambra, J.F.; Güemez, M.B.; Barrio, V.L.; Requies, J.; Sánchez-Sánchez, M.C.; Navarro, R.M. Effect of $\mathrm{ZrO} 2$ addition on $\mathrm{Ni} / \mathrm{Al} 2 \mathrm{O} 3$ catalyst to produce $\mathrm{H} 2$ from glycerol. Int. J. Hydrog. Energy 2012, 37, 7084-7093. [CrossRef]

74. Dou, B.; Dupont, V.; Rickett, G.; Blakeman, N.; Williams, P.T.; Chen, H.; Ding, Y.; Ghadiri, M. Hydrogen production by sorption-enhanced steam reforming of glycerol. Bioresour. Technol. 2009, 100, 3540-3547. [CrossRef] [PubMed]

75. Kamonsuangkasem, K.; Therdthianwong, S.; Therdthianwong, A. Hydrogen production from yellow glycerol via catalytic oxidative steam reforming. Fuel Process. Technol. 2013, 106, 695-703. [CrossRef]

76. Tuza, P.V.; Manfro, R.L.; Ribeiro, N.F.P.; Souza, M.M.V.M. Production of renewable hydrogen by aqueous-phase reforming of glycerol over Ni-Cu catalysts derived from hydrotalcite precursors. Renew. Energy 2013, 50, 408-414. [CrossRef]

77. Liu, Y.; Farrauto, R.; Lawal, A. Autothermal reforming of glycerol in a dual layer monolith catalyst. Chem. Eng. Sci. 2013, 89, 31-39. [CrossRef] 
78. Dauenhauer, P.J.; Salge, J.R.; Schmidt, L.D. Renewable hydrogen by autothermal steam reforming of volatile carbohydrates. J. Catal. 2006, 244, 238-247. [CrossRef]

79. Xu, D.; Wang, S.; Hu, X.; Chen, C.; Zhang, Q.; Gong, Y. Catalytic gasification of glycine and glycerol in supercritical water. Int. J. Hydrog. Energy 2009, 34, 5357-5364. [CrossRef]

80. Johnson, R.B. The treatment of ketosis with glycerol and propylene glycol. Cornell Vet. 1954, 44, 6-21.

81. Cottrill, B.; Berry, P.; Smith, C. Opportunities and Implications of Using Co-Products from Biofuel Production as Feeds for Livestock; Citeseer: Princeton, NJ, USA, 2007.

82. Drackley, J.K. Opportunities for glycerol use in dairy diets. In Proceedings of the Four-State Dairy Nutrition and Management Conference, Dubuque, Iowa, 11-12 June 2008; p. 113.

83. Bodarski, R.; Wertelecki, T.; Bommer, F.; Gosiewski, S. The changes of metabolic status and lactation performance in dairy cows under feeding TMR with glycerin [glycerol] supplement at periparturient period. Electron. J. Pol. Agric. Univ. Ser. Anim. Husb. 2005, 84, 1-9.

84. Swiatkiewicz, S.; Koreleski, J. Effect of crude glycerin level in the diet of laying hens on egg performance and nutrient utilization. Poult. Sci. 2009, 88, 615-619. [CrossRef]

85. McLea, L.; Ball, M.E.E.; Kilpatrick, D.; Elliott, C. The effect of glycerol inclusion on broiler performance and nutrient digestibility. Br. Poult. Sci. 2011, 52, 368-375. [CrossRef]

86. Hampy, K.R.; Kellogg, D.W.; Coffey, K.P.; Kegley, E.B.; Caldwell, J.D.; Lee, M.S.; Akins, M.S.; Reynolds, J.L.; Moore, J.C.; Southern, K.D. Glycerol as a supplemental energy source for meat goats. AAES Res. Ser. 2008, $553,63-64$.

87. Kholif, A.E. Glycerol use in dairy diets: A systemic review. Anim. Nutr. 2019, 5, 209-216. [CrossRef] [PubMed]

88. Cheng, L.; Liu, L.; Ye, X.P. Acrolein Production from Crude Glycerol in Sub-and Super-Critical Water. J. Am. Oil Chem. Soc. 2013, 90, 601-610. [CrossRef]

89. San Kong, P.; Aroua, M.K.; Daud, W.M.A.W. Conversion of crude and pure glycerol into derivatives: A feasibility evaluation. Renew. Sustain. Energy Rev. 2016, 63, 533-555. [CrossRef]

90. Kamzolova, S.V.; Fatykhova, A.R.; Dedyukhina, E.G.; Anastassiadis, S.G.; Golovchenko, N.P.; Morgunov, I.G. Citric acid production by yeast grown on glycerol-containing waste from biodiesel industry. Food Technol. Biotechnol. 2011, 49, 65-74.

91. Steinig, G.H.; Livingston, A.G.; Stuckey, D.C. Bioconversion of hydrophobic compounds in a continuous closed-gas-loop bioreactor: Feasibility assessment and epoxide production. Biotechnol. Bioeng. 2000, 70, 553-563. [CrossRef]

92. Wallace, S.; Balskus, E.P. Opportunities for merging chemical and biological synthesis. Curr. Opin. Biotechnol. 2014, 30, 1-8. [CrossRef]

93. Uprety, B.K.; Reddy, J.V.; Dalli, S.S.; Rakshit, S.K. Utilization of microbial oil obtained from crude glycerol for the production of polyol and its subsequent conversion to polyurethane foams. Bioresour. Technol. 2017, 235, 309-315. [CrossRef]

94. Samavi, M.; Uprety, B.K.; Rakshit, S. Bioconversion of Poplar Wood Hemicellulose Prehydrolysate to Microbial Oil Using Cryptococcus curvatus. Appl. Biochem. Biotechnol. 2019, 189, 626-637. [CrossRef]

95. Zhang, D.; Feng, X.; Zhou, Z.; Zhang, Y.; Xu, H. Economical production of poly ( $\gamma$-glutamic acid) using untreated cane molasses and monosodium glutamate waste liquor by Bacillus subtilis NX-2. Bioresour. Technol. 2012, 114, 583-588. [CrossRef]

96. Da Silva, G.P.; Mack, M.; Contiero, J. Glycerol: A promising and abundant carbon source for industrial microbiology. Biotechnol. Adv. 2009, 27, 30-39. [CrossRef] [PubMed]

97. Kim, J.-H.; Block, D.E.; Mills, D.A. Simultaneous consumption of pentose and hexose sugars: An optimal microbial phenotype for efficient fermentation of lignocellulosic biomass. Appl. Microbiol. Biotechnol. 2010, 88, 1077-1085. [CrossRef] [PubMed]

98. Dharmadi, Y.; Murarka, A.; Gonzalez, R. Anaerobic fermentation of glycerol by Escherichia coli: A new platform for metabolic engineering. Biotechnol. Bioeng. 2006, 94, 821-829. [CrossRef]

99. Karamerou, E.E.; Webb, C. Cultivation modes for microbial oil production using oleaginous yeasts-A review. Biochem. Eng. J. 2019, 151, 107322. [CrossRef]

100. Uprety, B.K.; Venkatesagowda, B.; Rakshit, S.K. Current prospects on production of microbial lipid and other value-added products using crude glycerol obtained from biodiesel industries. Bioenergy Res. 2017, 10, 1117-1137. [CrossRef] 
101. Beopoulos, A.; Cescut, J.; Haddouche, R.; Uribelarrea, J.-L.; Molina-Jouve, C.; Nicaud, J.-M. Yarrowia lipolytica as a model for bio-oil production. Prog. Lipid Res. 2009, 48, 375-387. [CrossRef]

102. Thevenieau, F.; Nicaud, J.-M. Microorganisms as sources of oils. OCL 2013, 20, D603. [CrossRef]

103. Sun, X.-M.; Ren, L.-J.; Zhao, Q.-Y.; Ji, X.-J.; Huang, H. Enhancement of lipid accumulation in microalgae by metabolic engineering. Biochim. Biophys. Acta (BBA)-Mol. Cell Biol. Lipids 2019, 1864, 552-566. [CrossRef]

104. Scott, S.A.; Davey, M.P.; Dennis, J.S.; Horst, I.; Howe, C.J.; Lea-Smith, D.J.; Smith, A.G. Biodiesel from algae: Challenges and prospects. Curr. Opin. Biotechnol. 2010, 21, 277-286. [CrossRef]

105. Garay, L.A.; Boundy-Mills, K.L.; German, J.B. Accumulation of high-value lipids in single-cell microorganisms: A mechanistic approach and future perspectives. J. Agric. Food Chem. 2014, 62, 2709-2727. [CrossRef]

106. Liang, Y.; Cui, Y.; Trushenski, J.; Blackburn, J.W. Converting crude glycerol derived from yellow grease to lipids through yeast fermentation. Bioresour. Technol. 2010, 101, 7581-7586. [CrossRef]

107. Fakas, S.; Papanikolaou, S.; Galiotou-Panayotou, M.; Komaitis, M.; Aggelis, G. Biochemistry and Biotechnology of Single Cell Oil; University of Patras: Patras, Greece, 2008; pp. 38-60.

108. Martínez, E.J.; Raghavan, V.; González-Andrés, F.; Gómez, X. New biofuel alternatives: Integrating waste management and single cell oil production. Int. J. Mol. Sci. 2015, 16, 9385-9405. [CrossRef] [PubMed]

109. Ratledge, C.; Wynn, J.P. The biochemistry and molecular biology of lipid accumulation in oleaginous microorganisms. Adv. Appl. Microbiol. 2002, 51, 1-52. [PubMed]

110. Huang, C.; Chen, X.-F.; Xiong, L.; Ma, L.-L.; Chen, Y. Single cell oil production from low-cost substrates: The possibility and potential of its industrialization. Biotechnol. Adv. 2013, 31, 129-139. [CrossRef]

111. Uprety, B.K.; Rakshit, S.K. Compositional shift in fatty acid profiles of lipids obtained from oleaginous yeasts upon the addition of essential oil from Citrus sinensis L. Appl. Biochem. Biotechnol. 2017, 183, 1158-1172. [CrossRef] [PubMed]

112. Uprety, B.K.; Rakshit, S.K. Use of essential oils from various plants to change the fatty acids profiles of lipids obtained from oleaginous yeasts. J. Am. Oil Chem. Soc. 2018, 95, 135-148. [CrossRef]

113. Suutari, M.; Priha, P.; Laakso, S. Temperature shifts in regulation of lipids accumulated byLipomyces starkeyi. J. Am. Oil Chem. Soc. 1993, 70, 891-894. [CrossRef]

114. Duarte, S.H.; de Andrade, C.C.P.; Ghiselli, G.; Maugeri, F. Exploration of Brazilian biodiversity and selection of a new oleaginous yeast strain cultivated in raw glycerol. Bioresour. Technol. 2013, 138, 377-381. [CrossRef]

115. Fakas, S.; Papanikolaou, S.; Batsos, A.; Galiotou-Panayotou, M.; Mallouchos, A.; Aggelis, G. Evaluating renewable carbon sources as substrates for single cell oil production by Cunninghamella echinulata and Mortierella isabellina. Biomass Bioenergy 2009, 33, 573-580. [CrossRef]

116. Ardi, M.S.; Aroua, M.K.; Hashim, N.A. Progress, prospect and challenges in glycerol purification process: A review. Renew. Sustain. Energy Rev. 2015, 42, 1164-1173. [CrossRef]

117. Tang, S.; Boehme, L.; Lam, H.; Zhang, Z. Pichia pastoris fermentation for phytase production using crude glycerol from biodiesel production as the sole carbon source. Biochem. Eng. J. 2009, 43, 157-162. [CrossRef]

118. Gao, Z.; Ma, Y.; Wang, Q.; Zhang, M.; Wang, J.; Liu, Y. Effect of crude glycerol impurities on lipid preparation by Rhodosporidium toruloides yeast 32489. Bioresour. Technol. 2016, 218, 373-379. [CrossRef] [PubMed]

119. Mothes, G.; Schnorpfeil, C.; Ackermann, J.U. Production of PHB from crude glycerol. Eng. Life Sci. 2007, 7, 475-479. [CrossRef]

120. Papanikolaou, S.; Fakas, S.; Fick, M.; Chevalot, I.; Galiotou-Panayotou, M.; Komaitis, M.; Marc, I.; Aggelis, G. Biotechnological valorisation of raw glycerol discharged after bio-diesel (fatty acid methyl esters) manufacturing process: Production of 1,3-propanediol, citric acid and single cell oil. Biomass Bioenergy 2008, 32, 60-71. [CrossRef]

121. Liu, L.-P.; Hu, Y.; Lou, W.-Y.; Li, N.; Wu, H.; Zong, M.-H. Use of crude glycerol as sole carbon source for microbial lipid production by oleaginous yeasts. Appl. Biochem. Biotechnol. 2017, 182, 495-510. [CrossRef]

122. Samavi, M.; Rakshit, S. Utilization of Microbial Oil from Poplar Wood Hemicellulose Prehydrolysate for the Production of Polyol Using Chemo-enzymatic Epoxidation. Biotechnol. Bioprocess Eng. 2020, 25, 1-9.

123. Drozdzynska, A.; Leja, K.; Czaczyk, K. Biotechnological production of 1,3-propanediol from crude glycerol. Biotechnol. J. Biotechnol. Comput. Biol. Bionanotechnol. 2011, 92-100.

124. Xu, Y.; Shang, S.; Huang, J. Crystallization behavior of poly (trimethylene terephthalate)-poly (ethylene glycol) segmented copolyesters/multi-walled carbon nanotube nanocomposites. Polym. Test. 2010, 29, 1007-1013. [CrossRef] 
125. González-Pajuelo, M.; Meynial-Salles, I.; Mendes, F.; Soucaille, P.; Vasconcelos, I. Microbial conversion of glycerol to 1,3-propanediol: Physiological comparison of a natural producer, Clostridium butyricum VPI 3266, and an engineered strain, Clostridium acetobutylicum DG1 (pSPD5). Appl. Environ. Microbiol. 2006, 72, 96-101. [CrossRef]

126. Drożdżyńska, A.; Pawlicka, J.; Kubiak, P.; Kośmider, A.; Pranke, D.; Olejnik-Schmidt, A.; Czaczyk, K. Conversion of glycerol to 1,3-propanediol by Citrobacter freundii and Hafnia alvei-Newly isolated strains from the Enterobacteriaceae. New Biotechnol. 2014, 31, 402-410. [CrossRef]

127. Saxena, R.K.; Anand, P.; Saran, S.; Isar, J. Microbial production of 1,3-propanediol: Recent developments and emerging opportunities. Biotechnol. Adv. 2009, 27, 895-913. [CrossRef] [PubMed]

128. Da Silva, G.P.; De Lima, C.J.B.; Contiero, J. Production and productivity of 1,3-propanediol from glycerol by Klebsiella pneumoniae GLC29. Catal. Today 2015, 257, 259-266. [CrossRef]

129. Jiang, W.; Wang, S.; Wang, Y.; Fang, B. Key enzymes catalyzing glycerol to 1,3-propanediol. Biotechnol. Biofuels 2016, 9, 57. [PubMed]

130. Samul, D.; Leja, K.; Grajek, W. Impurities of crude glycerol and their effect on metabolite production. Ann. Microbiol. 2014, 64, 891-898. [CrossRef] [PubMed]

131. Chatzifragkou, A.; Papanikolaou, S.; Dietz, D.; Doulgeraki, A.I.; Nychas, G.-J.E.; Zeng, A.-P. Production of 1,3-propanediol by Clostridium butyricum growing on biodiesel-derived crude glycerol through a non-sterilized fermentation process. Appl. Microbiol. Biotechnol. 2011, 91, 101-112. [CrossRef] [PubMed]

132. Jun, S.-A.; Moon, C.; Kang, C.-H.; Kong, S.W.; Sang, B.-I.; Um, Y. Microbial fed-batch production of 1,3-propanediol using raw glycerol with suspended and immobilized Klebsiella pneumoniae. Appl. Biochem. Biotechnol. 2010, 161, 491-501. [CrossRef]

133. Trchounian, A. Mechanisms for hydrogen production by different bacteria during mixed-acid and photo-fermentation and perspectives of hydrogen production biotechnology. Crit. Rev. Biotechnol. 2015, 35, 103-113. [CrossRef]

134. Maintinguer, S.I.; Hatanaka, R.R.; De Oliveira, J.E. Glycerol as a raw material for hydrogen production. In Biofuels-Status and Perspective; InTech: Rijeka, Croatia, 2015.

135. Hallenbeck, P.C. Fermentative hydrogen production: Principles, progress, and prognosis. Int. J. Hydrog. Energy 2009, 34, 7379-7389. [CrossRef]

136. Mangayil, R.; Karp, M.; Santala, V. Bioconversion of crude glycerol from biodiesel production to hydrogen. Int. J. Hydrog. Energy 2012, 37, 12198-12204. [CrossRef]

137. Lo, Y.-C.; Chen, X.-J.; Huang, C.-Y.; Yuan, Y.-J.; Chang, J.-S. Dark fermentative hydrogen production with crude glycerol from biodiesel industry using indigenous hydrogen-producing bacteria. Int. J. Hydrog. Energy 2013, 38, 15815-15822. [CrossRef]

138. Pott, R.W.M.; Howe, C.J.; Dennis, J.S. Photofermentation of crude glycerol from biodiesel using Rhodopseudomonas palustris: Comparison with organic acids and the identification of inhibitory compounds. Bioresour. Technol. 2013, 130, 725-730. [CrossRef] [PubMed]

139. Chookaew, T.; Prasertsan, P.; Ren, Z.J. Two-stage conversion of crude glycerol to energy using dark fermentation linked with microbial fuel cell or microbial electrolysis cell. New Biotechnol. 2014, 31, 179-184. [CrossRef]

140. Pinazo, J.M.; Domine, M.E.; Parvulescu, V.; Petru, F. Sustainability metrics for succinic acid production: A comparison between biomass-based and petrochemical routes. Catal. Today 2015, 239, 17-24. [CrossRef]

141. Succinic Acid: Market by Type (Biobased, Petro-based), Application (Polyurethane, Resins, Coatings EPigments, Pharmaceuticals, Plasticizers, Food \& Beverage, PBS/PBST, Solvents E Lubricants, De-Icer Solutions, Personal Care, and Others), and by Region-Global Forecast to 2021; Markets and Markets Research Private Ltd.: Pune, India, July 2016; p. 208. Available online: https:/www.marketsandmarkets.com/Market-Reports/succinic-acidmarket-402.html (accessed on 16 April 2020).

142. Byun, M.Y.; Kim, J.S.; Baek, J.H.; Park, D.-W.; Lee, M.S. Liquid-Phase Hydrogenation of Maleic Acid over Pd/A12O3 Catalysts Prepared via Deposition-Precipitation Method. Energies 2019, 12, 284. [CrossRef]

143. Guettler, M.V.; Rumler, D.; Jain, M.K. Actinobacillus succinogenes sp. nov., a novel succinic-acid-producing strain from the bovine rumen. Int. J. Syst. Evol. Microbiol. 1999, 49, 207-216. [CrossRef]

144. Lee, P.; Lee, S.; Hong, S.; Chang, H. Isolation and characterization of a new succinic acid-producing bacterium, Mannheimia succiniciproducens MBEL55E, from bovine rumen. Appl. Microbiol. Biotechnol. 2002, 58, 663-668. [PubMed] 
145. Lee, P.C.; Lee, S.Y.; Chang, H.N. Kinetic study on succinic acid and acetic acid formation during continuous cultures of Anaerobiospirillum succiniciproducens grown on glycerol. Bioprocess Biosyst. Eng. 2010, 33, 465-471. [CrossRef]

146. Lin, S.K.C.; Du, C.; Koutinas, A.; Wang, R.; Webb, C. Substrate and product inhibition kinetics in succinic acid production by Actinobacillus succinogenes. Biochem. Eng. J. 2008, 41, 128-135. [CrossRef]

147. Scholten, E.; Renz, T.; Thomas, J. Continuous cultivation approach for fermentative succinic acid production from crude glycerol by Basfia succiniciproducens DD1. Biotechnol. Lett. 2009, 31, 1947. [CrossRef]

148. Gao, C.; Yang, X.; Wang, H.; Rivero, C.P.; Li, C.; Cui, Z.; Qi, Q.; Lin, C.S.K. Robust succinic acid production from crude glycerol using engineered Yarrowia lipolytica. Biotechnol. Biofuels 2016, 9, 179. [CrossRef]

149. Kang, Z.; Du, L.; Kang, J.; Wang, Y.; Wang, Q.; Liang, Q.; Qi, Q. Production of succinate and polyhydroxyalkanoate from substrate mixture by metabolically engineered Escherichia coli. Bioresour. Technol. 2011, 102, 6600-6604. [CrossRef] [PubMed]

150. Lee, S.Y.; Hong, S.H.; Lee, S.H.; Park, S.J. Fermentative production of chemicals that can be used for polymer synthesis. Macromol. Biosci. 2004, 4, 157-164. [CrossRef] [PubMed]

151. Carvalho, M.; Matos, M.; Roca, C.; Reis, M.A.M. Succinic acid production from glycerol by Actinobacillus succinogenes using dimethylsulfoxide as electron acceptor. New Biotechnol. 2014, 31, 133-139. [CrossRef] [PubMed]

152. Lotfy, W.A.; Ghanem, K.M.; El-Helow, E.R. Citric acid production by a novel Aspergillus niger isolate: II. Optimization of process parameters through statistical experimental designs. Bioresour. Technol. 2007, 98, 3470-3477. [CrossRef]

153. Levinson, W.E.; Kurtzman, C.P.; Kuo, T.M. Characterization of Yarrowia lipolytica and related species for citric acid production from glycerol. Enzyme Microb. Technol. 2007, 41, 292-295. [CrossRef]

154. Kamzolova, S.V.; Shishkanova, N.V.; Il'Chenko, A.P.; Sal'nikova, I.V.; Arzumanov, T.E.; Finogenova, T.V. Biosynthesis of citric and isocitric acids by Yarrowia lipolytica N1, at various concentrations of oxygen and iron in the culture medium. Appl. Biochem. Microbiol. 1997, 33, 359-363.

155. Imandi, S.B.; Bandaru, V.R.; Somalanka, S.R.; Garapati, H.R. Optimization of medium constituents for the production of citric acid from byproduct glycerol using Doehlert experimental design. Enzyme Microb. Technol. 2007, 40, 1367-1372. [CrossRef]

156. Yalcin, S.K.; Bozdemir, M.T.; Ozbas, Z.Y. Citric acid production by yeasts: Fermentation conditions, process optimization and strain improvement. Curr. Res.Technol. Educ. Top. Appl. Microbiol. Microb. Biotechnol. 2010, 9, 1374-1382.

157. Rywinska, A.; Rymowicz, W.; Zarowska, B.; Wojtatowicz, M. Biosynthesis of citric acid from glycerol by acetate mutants of Yarrowia lipolytica in fed-batch fermentation. Food Technol. Biotechnol. 2009, 47, 1-6. 